\section{Genetics besieged}

\section{David Joravsky}

Lysenko and the Tragedy of Soviet Science. By Valery N. Soyfer. Rutgers University Press: 1994. Pp. 379. \$39.95.

As soon as Soviet intellectuals probed Gorbachev's glasnost and discovered that it was for real, rage erupted, blowing away all semblance of respect for the Soviet system. This history of the Lysenko affair emerged in that collapse of conformism, that eruption of fury, which had been extremes, to ground moral judgement on deep probing of historical cause and effect - in short, to get beyond melodrama and discover history as genuine tragedy.

Candid analysis of "schizoid" elements in his own career - to take an obvious example - might have illuminated the patron-and-client pattern that helps to explain the great paradox of Soviet science after Stalin: an ebbing of ideological intrusion, a great increase in the number of scientists, and a marked decline in creativity. Soyfer, as I read the record, was a protégé of N. P. Dubinin, a geneticist who defended his embattled discipline under Stalin and led its rebuilding afterwards,

\section{IMAGE UNAVAILABLE FOR COPYRIGHT REASONS}

\section{Agricultural propaganda - a Soviet poster showing the benefits to be reaped from the "Cultivation of the Virgin Lands" (1950).}

accumulating for a long time. Beginning in the 1950 s the author had been making a Soviet career as a molecular biologist, while also quietly collecting materials about the 35-year war that "agrobiologists", as the Lysenkoites called themselves, waged against genuine biology. Soyfer reached his breaking point in 1980 , before glasnost, when he signed a dissident petition on behalf of Sakharov, was fired from his job, and turned to the writing of Power and Science, as this book was originally called. Glasnost enabled him to publish a chunk of it in a Soviet mass circulation magazine (also in Nature 339, 45 and 340, 732; 1989); the whole Russian text appeared in the United States - and there, at George Mason University, he has wound up as an émigré.

He pictures himself as a leader of "the defiant outcasts" as early as the 1950s, while other people felt "forced to lead schizoid lives", pretending to revere a system that they actually loathed. His story is constructed of such dichotomies; strong, weak; smart, dumb; heroes, villains; praise, blame. He is too excited to explore the gradients between dichotomous but earned the contempt of other scientists by his grotesque self-conceit. Soyfer echoes this contempt in the present book, but a history of genetics that he published in Moscow in 1970 (Ocherki istorii molekuliarnoi genetiki) exalted Dubinin in its grandiose conclusion that genetics would bring evolution under human control, exchange Earth's living forms with other worlds, explain consciousness, create thinking animals, eliminate defective human genes and master "directed mutagenesis, which will place the organic world in the power of man" (p. 226).

Pseudo-Promethean blather was a characteristic of 'agrobiology' in the Stalin era, as Soyfer scornfully shows. What he does not stop to ponder is the contribution of genuine biologists to exaggerated hopes of benefit from applied science. Such vacuous vapouring as he learned from Dubinin in the post-Stalin era was merely amusing, without influence on men of power, as far as I know. The serious problem was the enthusiasm of the early years, when revolutionary leaders rallied genuine scientists to the enormous task of modernizing Russia's peasant agri- culture. Bosses and biologists shared the dream of quickly "overtaking and surpassing" the US Department of Agriculture, whose network of research centres and "extension services" proved the beneficent power of government and science working together for the advancement of farming. That dream inspired the creation of the Lenin Academy of Agricultural Sciences, the organizing centre for the legendary labours of N. I. Vavilov, who did not protest when his "law of homologous series" was acclaimed as the biological equivalent of Mendeleev's periodic table. Soyfer repeats that claim without criticism and ignores Vavilov's forecast of biologists "sculpting organic forms at will", which foreshadowed the slogans that the 'agrobiologists' would use against him.

To be sure, biologists' modest indulgence in romantic confusion of dream and reality was only a small source of the violent nightmare that Communist leaders brought to agriculture and to biological science with the forced collectivization of 1929 to 1932 . But it was $a$ source of that berserk leap forward into total confusion between will and understanding, the will of tyrants, the understanding of tyrannized servants. Angrily disappointed with scientists' dreams, Communist bosses turned to the nostrums of semiliterate cranks. The protracted conflict that ensued favoured Lysenko and his crew in the 1930s and 1940s and turned against them in the 1950s and 1960s. "The Party" - never the monolith it pretended to be, always a complex body in evolution moved from expectations of miraculous aid from science to pretensions of miraculous aid from 'agrobiology', and finally to the realization that no miracles are to be found, whether in science or pseudoscience, that might help violent bosses to modernize the peasant agriculture of an underdeveloped country.

The first solid history of this process was written by Zhores Medvedev, a dissident of the 1960 s who really was cast out of his native land for insistently criticizing its regime (The Rise and Fall of $T$. D. Lysenko, Columbia University Press, 1969). The other standard history, worked out in greater detail on a broader canvas, was done by myself, an outside observer who mined the Soviet record and interviewed participants of both 'camps' (The Lysenko Affair, Harvard University Press/University of Chicago Press, 1970/1986). Soyfer pays scant attention, mostly dismissive, to Medvedev's book, and none at all to mine - except to accuse me of crediting Lysenko's earliest work with scientific merit. If he had read my book, he would have seen that I did nothing of the sort, and, more importantly, he might have found his way out of Kremlinology, the explanation of Soviet history by appeal to the little minds of 
Stalin or Khrushchev and to intrigues at their court. Intermittently Soyfer declares that "the system" was to blame for Lysenkoism, but he does not get beyond the empty declaration. $\mathrm{He}$ does not analyse 'the system' in the process of historical development, or confront the difference between analysis of cause and effect and assignment of blame or credit. Soviet histories were written this way before glasnost, in reverence instead of rage. Now pluses and minuses have been reversed, but the crude algorithm persists.

Official Soviet histories credited the Communists with modernizing a backward country; Soyfer blames them for ruining "a once bountiful land, with the world's largest sown area and pasturage", for destroying "the well-organized system that Lisitsyn, Vavilov and others had established to maintain pure seed production" and wrecking "the leading position that Russia once held in genetics". It is painful to see fantasy still projected upon Russia's agricultural realities - in retrospection now instead of anticipation and embarrassing to read Soyfer's boasts of Russian priorities in genetics, which recall claims that provoked worldwide laughter not long ago. I am not doubting that genetic science made remarkable progress in Russia during the 1920s. I am merely noting that it did so under a Communist regime, while applied science in agriculture did not make such progress. Both the official histories of the Soviet period and the simplistic inversions of glasnost historiography ignore the hard question: why did revolutionary commissars repeat the forceful top-down pattern of modernization that began with Peter the Great in the early eighteenth century, intensifying servile relationships and the frightful inefficiencies that accompany them?

Soyfer's book is nevertheless a useful addition to the scholarly literature. $\mathrm{He}$ has done some digging in archives and summarizes a good deal of what others have uncovered. More significant are the materials he collected over many years from some of the major participants, although he is sometimes naive in repeating their stories as gospel. For example, the tale of Stalin's final interview with Vavilov, which reached Soyfer at fourth hand almost 50 years after the event, has the style and substance of Soviet folklore.

Soyfer's most striking achievement is his portrait of Lysenko, whom he observed and interviewed at length over a considerable period of time. Semiliterate, charismatic, fanatic, wilfully contemptuous of careful reasoning with hard evidence - all that has been said of Lysenko in previous works, but never with the persuasive detail and intimate evidence that Soyfer provides. He even sympathizes with the brute in his fall from power, since the "personal drama had nothing to do with the fate of Lysenkoism as a social phenomenon". This simplistic disjunction is unwittingly revealing of the extreme separation of power from responsibility that has plagued the Russian system for a very long time, even in the minds of those who rebel against it.

David Joravsky is in the Department of History, Northwestern University, 1881 Sheridan Road, Evanston, Illinois 602082220, USA.

\section{Abamp to zyometry by way of mingel}

\section{Walter Gratzer}

The Dent Dictionary of Measurement. By Mike Darton and John Clark. Dent: 1994. Pp. 538. £30.

"All knowledge", Dr Johnson declared, "is of some value. There is nothing so minute or inconsiderable, that I would not rather know it than not." I wonder though whether even he might not have drawn the line this side of being instructed that the Danes measured dry volumes by the tønde, one of which was the equivalent of 144 pots, 8 skaeppe or 4 fjerdings; or that in ancient Russia there were 40 funte to a pud and 30 pudi to a packen. Consider furthermore that in the Iberian peninsula I have of course only Messrs Darton and Clark's word for it - an almude (that is to say 16 octavillos) is one-twelfth part of a fanega, but whereas the Spanish fanega makes up 55.50 litres (or, as Darton and Clark helpfully add, 12.21 UK gallons or pitch and the like, not to mention the ranges of instruments - including the Bflat alto flugelhorn $\left(2^{1 / 2}\right.$ octaves from $\mathrm{E}$ below middle $\mathrm{C}$, whereas a psaltery will comfortably manage 4 octaves).

There is of course plenty to bemuse the scientist, such as instruments for every imaginable measurement, and especially units - units current, units defunct and units that never caught on in the first place; so while the slug survives amongst the pounds and the feet, the glug was stillborn as the metric unit of mass, nor did the inferno find favour as a measure of the temperature of stars. The dollar is not only a dollar (etym.: thaler, from Joachimsthaler, a coin minted from silver, mined in Sankt Joachimsthal, now Jachymov in the Czech Republic, first issued in 1519), but also a unit of reactivity, equal to that contributed by delayed neutrons. Pain, it seems is measured by the dol (in a dolorimeter) and herrings by the cran.

The standard of accuracy of the definitions is, so far as I am able to judge, high, though the odd mistake does crop up: the Bohr magneton, for instance, does not come in joules per kelvin, the rate constant of a reaction is misdefined, there is a wholly inscrutable entity called a biomolecule, and surely nobody.now believes that the direction that water swirls down the plug-hole changes at the equator in accordance with the Coreolis force? Tested for comprehensiveness the dictionary came through triumphantly; I looked up first the Scoville scale, which measures the hotness of chilli peppers, and was rewarded with the information that a standard chilli registers about $5,000^{\circ}$, and the incandescent kind $8,000^{\circ}$. Among the few units I failed to find was the hardness scale for pencils, and neither was there any entry under degrees Twaddle, which (if memory serves) measure alkali titre. There is, on the other hand, a great deal of repetition: the seven sizes of wine bottles from the magnum to the nebuchadnezzar are all tabulated under each, there is the halfmile ("see half a mile"), as well as the mile with all its constituent parts, and units tend to recur under milli, micro, centi and the rest - but oddly, the smallest is atto, as in attomole, and zetto does not appear (though it is true that it is very small). I cannot remember which physicist it was who suggested that zetto may have originated as a misprint for zeppo, after the forgotten Marx brother, and that the zettomole should therefore be followed by the chicomole, the harpomole and the grouchomole. (As the last corresponds to less than one molecule, it could also perhaps be termed the benveniste.)

So, then, if you are not stirred by the discovery that 1 schtoff contains 10 charki, while 10 schtoffs make a vedro, and more, that the schtoff (of which there are 0.9259 in two UK pints, though only 0.7722 in two US pints) is identical to the old Dutch 